\title{
Evaluating mortality sources for the Vulnerable pudu Pudu puda in Chile: implications for the conservation of a threatened deer
}

\author{
Eduardo A. Silva - Rodríguez, Claudio Verdugo, O. Alejandro Aleuy \\ James G. Sanderson, Gabriel R. Ortega-Solís, Felipe Osorio-Zúñaga and \\ D A N I L L GonZÁleZ - A C UÑ A
}

\begin{abstract}
We assessed the importance of potential sources of mortality for the Vulnerable southern pudu Pudu puda in southern Chile using the clinical records of wildlife rehabilitation centres, necropsies of animals found in the field and a review of the diet of potential predators. To assess whether the identified mortality sources operate in nominally protected areas, we conducted a camera-trap survey in two areas to determine the presence of pudus and their potential predators. Predation by domestic dogs Canis lupus familiaris and car collisions were the commonest causes of pudu admissions to rehabilitation centres (35 of 44) and of deaths of animals encountered opportunistically in the field (seven of 14). Field data suggest that poaching could also be an important threat to pudus. Pudus were detected in both areas surveyed, accounting for $15.6 \%$ of mammal detections. Dogs accounted for $47.8 \%$ of all detections of potential predator species, followed by pumas Puma concolor (17.4\%), guignas Leopardus guigna (17.4\%) and chilla foxes Lycalopex griseus (17.4\%). The literature survey implicated only pumas as important pudu predators among native carnivores. Our data suggest that, aside from forest loss, dogs, road kills and probably poaching are important concerns for pudu conservation. Our frequent detections of free-ranging dogs associated with roads within nominally protected areas suggest that long-term efforts to conserve pudu will require not only the protection of remnant native forest but also
\end{abstract}

Eduardo A. Silva-Rodríguez (Corresponding author) Department of Wildlife Ecology and Conservation and School of Natural Resources and Environment, University of Florida, 110 Newins-Ziegler Hall, Gainesville, FL 32611-0430, USA. E-mail eduardosilva@ufl.edu

Claudio Verdugo*, O. Alejandro Aleuy and Gabriel R. Ortega-Solís Centro de Rehabilitación de Fauna Silvestre, Facultad de Ciencias Veterinarias, Universidad Austral de Chile, Valdivia, Chile.

JAmes G. SAnderson Wildlife Conservation Network, Los Altos, USA.

Felipe Osorio-Zúñiga Facultad de Ciencias, Universidad Austral de Chile, Valdivia, Chile.

Daniel GonZÁlez-Acuña Facultad de Medicina Veterinaria, Universidad de Concepción, Chillán, Chile.

*Also at: Department of Small Animal Clinical Sciences, College of Veterinary Medicine, University of Florida, Gainesville, USA.

Received 8 September 2008. Revision requested 18 December 2008. Accepted 28 January 2009. substantive environmental education to modify dog management near protected areas.

Keywords Chile, domestic dog, poaching, Pudu puda, Puma concolor, roadkills, South America, temperate forest

\section{Introduction}

The southern pudu Pudu puda is one of the smallest deer in the world reaching just $40 \mathrm{~cm}$ in height (Hershkovitz, 1982). It inhabits the South American temperate rainforest of Chile and Argentina, where it is endemic (Wemmer, 1998). The geographical distribution of the species ranges from $36^{\circ}$ to $49^{\circ} \mathrm{S}$ in Chile (Miller et al., 1973) and from $39^{\circ}$ to $43^{\circ} \mathrm{S}$ in Argentina (Meier \& Merino, 2007). It prefers dense understorey, secondary forest and native bamboo thickets (Eldridge et al., 1987; Meier \& Merino, 2007). The ecology of the species, however, remains mostly unknown.

The pudu is categorized as Vulnerable on the IUCN Red List (Jiménez \& Ramilo, 2008) and it is included in Appendix I of CITES (Wemmer, 1998; Weber \& Gonzalez, 2003). The total population of the species is thought to be $<$ 10,000 (Wemmer, 1998). The main threats to pudu are forest loss and fragmentation (Miller et al., 1973; Wemmer, 1998), and significant losses of temperate forests in southern Chile and Argentina have already occurred (Cavelier \& Tecklin, 2005). In addition to habitat loss, pudus are apparently threatened by poaching and predation by domestic dogs Canis lupus familiaris (Miller et al., 1973; Hershkovitz, 1982; Wemmer, 1998; Weber \& Gonzalez, 2003); however, these threats have not been assessed (Wemmer, 1998). In addition to various anthropogenic threats, pudus are preyed upon by native predators such as pumas Puma concolor (Rau et al., 1991; Rau \& Jiménez, 2002b) and potentially by other carnivores such as foxes (Lycalopex spp., Jiménez et al., 1991; Jiménez, 2007) and guignas Leopardus guigna (Hershkovitz, 1982, Freer, 2004).

Our objective was to evaluate the potential threats to pudu in southern Chile. In particular, we addressed sources of mortality by analysing the clinical records of wildlife rehabilitation centres and pudu mortality data collected in the field. This was complemented by reviewing the published 
dietary analyses of potential predators within the range of the pudu. To address whether these potential sources of mortality operate in protected areas, we assessed the presence of the pudu and its potential predators using camera traps.

\section{Methods}

\section{Causes of mortality}

Rehabilitation centres We evaluated causes of pudu mortality in the clinical records from the two main wildlife rehabilitation centres in southern Chile: at the Universidad de Concepción, Chillan, Bío-Bío District, and the Universidad Austral de Chile, Valdivia, Los Rios District (Fig. 1). These centres receive most of the injured animals found in their respective districts. At both Centres veterinary staff collect information on age, gender, origin of the animal and the circumstances in which the animal was found, and each animal is examined to establish a clinical diagnosis and treatment. In case of death, necropsies narrow the diagnosis (Woodford et al., 2000). We summarize the causes of arrival of pudus at the rehabilitation centres, clinical findings and mortality rates of animals received (number of pudu deaths/ number received) and the male:female and adult:fawn ratios.

Field mortality As a second source of information on pudu mortality we used data collected from two sites in southern Chile (Fig. 1). Centinela is a rural area in Los Ríos District where native forest has been reduced to fragments com- prising c. $23 \%$ of the land cover (Silva-Rodríguez, 2006). Chaquihual is an area in Chiloé Island, Los Lagos District, with c. $68 \%$ forest cover dominated by secondary forest and bamboo (Chusquea spp.) and was subject to selective logging during the period of study. Centinela was surveyed in 2006 and 2008 and Chaquihual during 2005. At both sites carcasses were located opportunistically (when driving or walking along roads) and using information provided by local people, with whom we spoke opportunistically. Mortality causes were determined by necropsy (Woodford et al., 2000) and using complementary information such as tracks and other signs of potential predators close to the carcasses. We considered that a pudu was killed by a predator only if its injuries were associated with haemorrhages, indicating the animal was alive at the time the injury occurred (DiMaio \& DiMaio, 2001). Otherwise, injuries were attributed to scavenging activity. Old carcasses and bones were classified as undetermined mortality causes. Information regarding recent poaching of pudus was opportunistically collected while conducting surveys for other purposes (Silva-Rodríguez, 2006) and when there was evidence of recent culling by local people (e.g. skins or body parts in homes).

\section{Diet of native predators}

Detection of carcasses of pudus killed by predators such as pumas or foxes is unlikely in forested areas. Therefore, we assessed the occurrence of pudu remains in carnivore scats
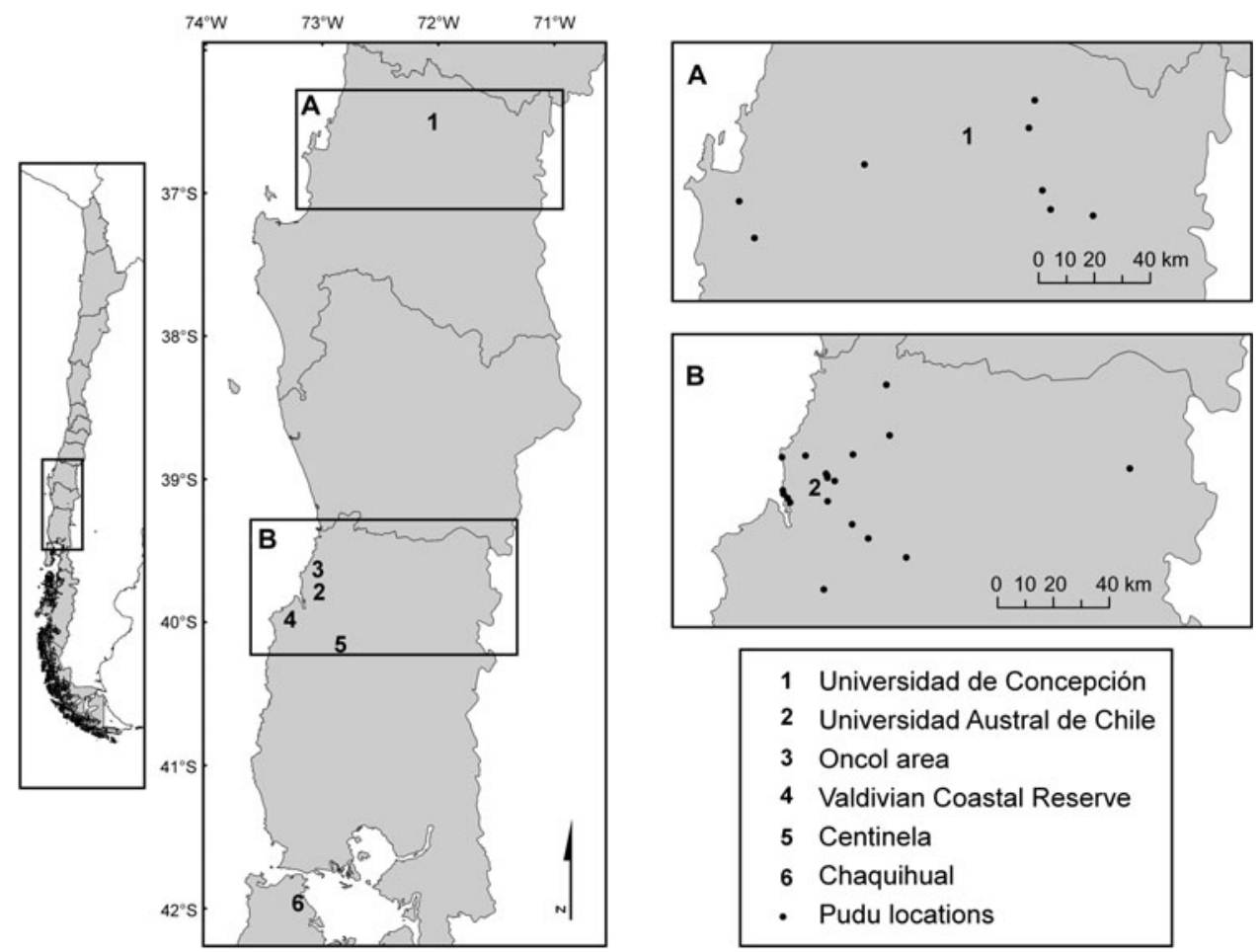

1 Universidad de Concepción

2 Universidad Austral de Chile

3 Oncol area

4 Valdivian Coastal Reserve

5 Centinela

6 Chaquihual

- Pudu locations

FIG. 1 Location of the rehabilitation centres and field sites considered in this study. Insets (A) and (B) show the location of origin of pudus received at Universidad de Concepción and Universidad Austral de Chile rehabilitation centres respectively. 
by reviewing published data on the diet of potential pudu predators within the distribution range of pudu. Our analysis included puma, guigna, chilla fox Lycalopex griseus, culpeo fox Lycalopex culpaeus and Darwin's fox Lycalopex fulvipes. From the data available we calculated the frequency of occurrence of pudus in the diet of each potential native carnivore. Frequency of occurrence was estimated as the number of scats in which pudu remains were found divided by the total number of scats analysed.

\section{Camera-trap surveys}

To estimate the relative occurrence of pudu and its predators we conducted camera-trap surveys in two private protected areas in the coastal range of Los Rios District (Fig. 1). In the Oncol area, dominated by primary and secondary evergreen forest, we conducted surveys in Oncol Park, Pilolcura and Pichicuyín (Fig. 1). In the Valdivian Coastal Reserve, which is the largest protected area in the coastal range of southern Chile ( $>60$,000 ha), we conducted surveys in Chaihuín and Colún, areas dominated by secondary forests and some Eucalyptus spp. plantations.

Camera trapping, the use of motion-triggered cameras set at bait stations or along animal trails, is a useful technique for mammal inventories in remote areas (Silveira et al., 2003). We surveyed for pudus and potential predators using seven cameras (three Snapshot Sniper; Duncan, USA, and four Woodland Outdoor Sports, Frankenmuth, USA). Cameras were placed at least $1 \mathrm{~km}$ apart from each other, 5$500 \mathrm{~m}$ from roads, for 21-28 days and recorded date and time when triggered. Surveys were from April 2007 to February 2008. Camera traps were alternated between the Oncol area and Valdivian Coastal Reserve. Failures and robbery of cameras resulted in unequal effort between the two areas but detections were standardized to effort. Relative abundance indices were calculated as the number of pudu photographs per 100 trap-days. In the case of pudus and dogs we also recorded the minimum number of different individuals detected. Individual pudus were considered different if a male and a female (Hershkovitz, 1982; Plate 1) were detected in the same camera trap or if different camera traps within a study site were visited in the same sampling period. The assumption that pudus in different cameras were different individuals is safe, given that the closest distance between two cameras that registered pudu photographs was $>3 \mathrm{~km}$, which is considerably larger than the largest diameter of a pudu home range (Eldridge et al., 1987). Individual dogs were identified based on major phenotypic differences.

\section{Results}

\section{Pudu mortality}

Data for 44 pudus were collected at the rehabilitation centres (29.5\% males, $61.4 \%$ females and $9.1 \%$ fawns). The primary causes of pudu arrival at centres were dog attacks and car hits (Fig. 2). Mortality of animals received was high: $56.8 \%$ died in spite of medical treatment. Mortality rate was
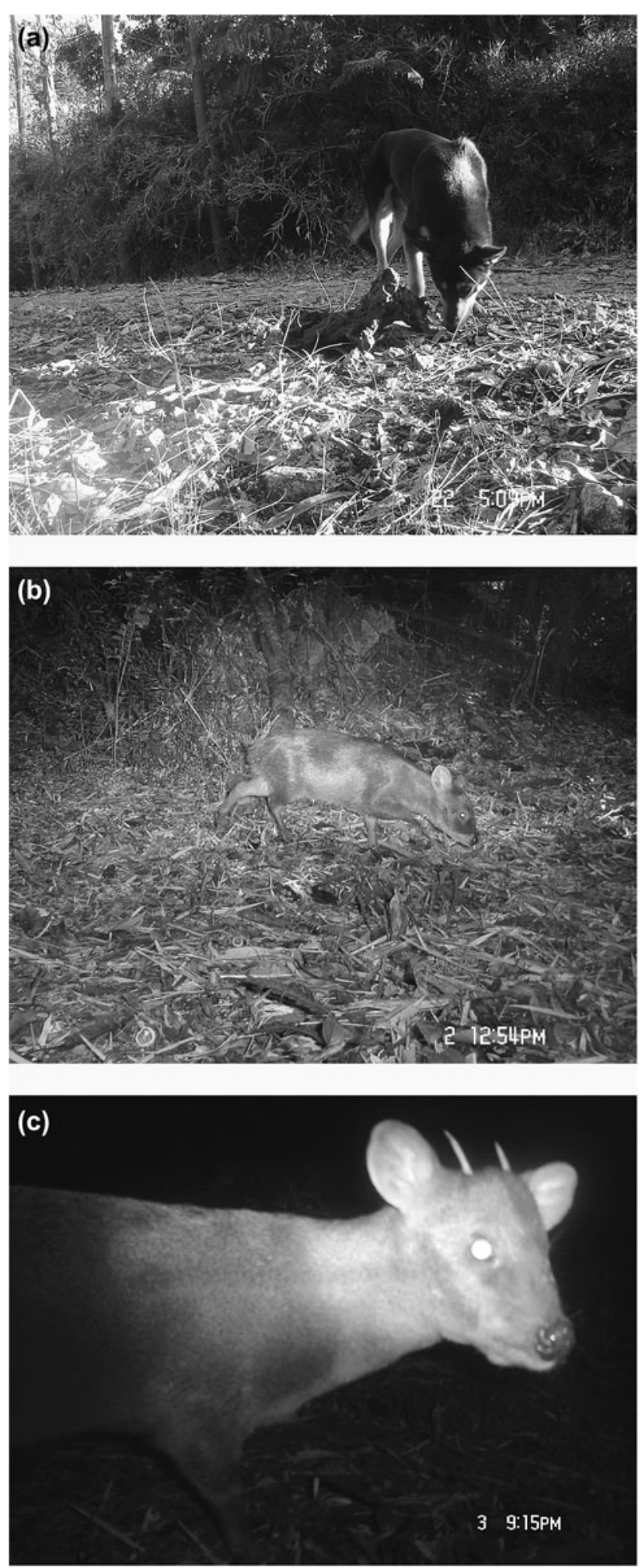

Plate 1 Camera trap photographs of (a) domestic dog in Colún, and (b) female and (c) male pudu recorded by the same camera in Chaihuín (Fig. 1). 
particularly high for those animals that had been hit by a car (69.2\%) and for those that had been attacked by dogs (68.2\%). Pudus injured by dogs presented politraumatism, puncture wounds, limb and lumbo-sacral fractures, thoracic and abdominal perforations and multiple abscesses, whereas animals hit by cars frequently presented policontusions, costal fractures, thoracic and lumbar vertebral fractures, cranioencephalic traumatism and haemothorax. Rhabdomyolysis (capture myopathy) was a common necropsy finding.

Seven dead pudus were identified in each of the sites. In Centinela three animals were killed by dogs, two by local people and two by car collisions. In Chaquihual two animals were killed by dogs, two by local people and mortality cause was not determined for three old carcasses.

\section{Predator diet}

Pudu remains were reported in $34.8 \%$ of 161 puma scats analysed and in all but two locations where puma diet has been studied and both species coexist (Table 1). The occurrence of pudu in the diet of small carnivores is low. Pudu is reported in $1.5 \%(\mathrm{n}=801)$ and $0.5 \%(\mathrm{n}=200)$ of the scats of Darwin's fox and guigna, respectively, and not in culpeo $(n=148)$ or chilla fox $(n=463)$ scats (Table 1$)$. In only two areas have the diets of puma and at least one other carnivore been assessed simultaneously. In both cases pudus were frequently detected in the diet of pumas $(26.5 \%$, Rau et al., 1991; 67.7\%, Zúñiga et al., 2005) and not detected in the diet of chillas (Martínez et al., 1993; Zúñiga et al., 2005) and guignas (Zúñiga et al., 2005).

\section{Occurrence of pudus and predators in protected areas}

Sixty-three independent photographs were obtained of eight mammal species (Table 2). The most frequent species

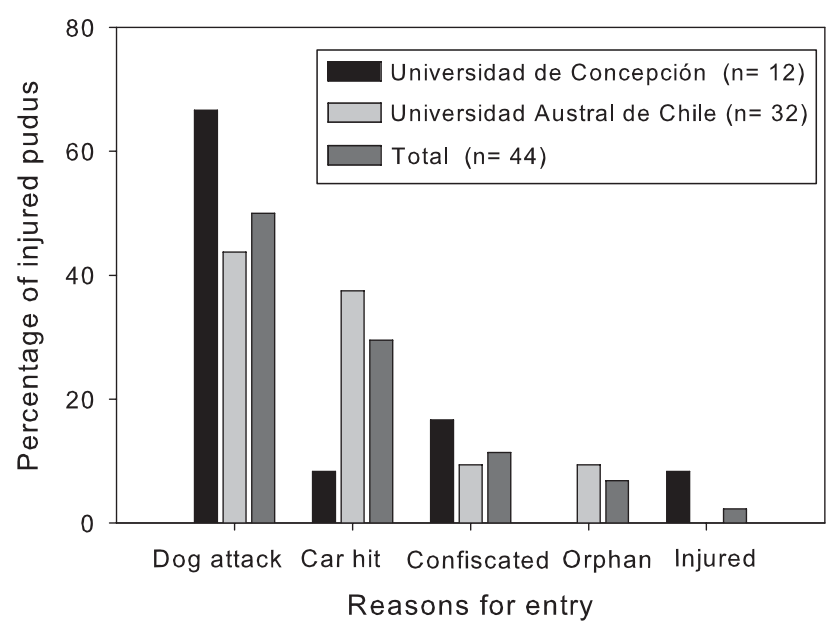

FIG. 2 Percentage of pudus received at two wildlife rehabilitation centres in southern Chile (2005-2008), categorized according to the reason for admission. recorded were domestic cattle Bos taurus (31.7\% of mammal detections), domestic $\operatorname{dog}(17.5 \%)$ and pudu (15.9\%). Within the Valdivian Coastal Reserve at least six different pudus were photographed by four different cameras and on 9 different days, whereas in the Oncol area pudus were detected only once. Dogs were detected frequently in both areas (Table 2), always on unpaved roads $(<50 \mathrm{~m})$. Ten different individuals were identified and six of them were detected in association with local people. Dogs alone accounted for $47.8 \%$ of the independent detections of potential predators. Pudus were never detected at the same camera as a dog or a puma. However, one individual was detected at the same camera as a chilla fox within a 24-hour period.

\section{Discussion}

\section{Mortality sources}

The analysis of rehabilitation centre records and collection of carcasses in the field are useful tools to identify wildlife threats but interpretation of such data requires caution (Ciucci et al., 2007; Mazaris et al., 2008). The main issue is that the causes of death or injury may have different probabilities of being detected (Ciucci et al., 2007). For example, an animal hit by a car is more likely to be found and transported to a rehabilitation centre (Spalding \& Forrester, 1993; Ciucci et al., 2007). In contrast, a poached animal or an animal affected by a disease is less likely to be reported (Ciucci et al., 2007).

Predation by dogs is suspected to be a major threat to pudus in human-dominated landscapes (Miller et al., 1973; Hershkovitz, 1982; Wemmer, 1998; Weber \& González, 2003). In such areas in southern Chile, dog densities can be as high as $7.3 \mathrm{~km}^{-2}$ (Silva-Rodríguez, 2006). In comparison to the highest densities reported for pumas in Chile (o.06 individuals km ${ }^{-2}$, for Patagonia; Franklin et al., 1999), this density of dogs represents an increase, by more than two orders of magnitude, in the abundance of predators in human-dominated landscapes, with potentially serious consequences for the persistence of pudus. In this situation even infrequent predation by dogs could have serious consequences for pudu populations. The rehabilitation centre records and field data presented here represent convergent evidence for the potential importance of dogs as predators of pudu (Fig. 2).

Our camera-trap data suggest that dogs could also be a problem within nominally protected areas (at least where roads are present), where they accounted for $45.8 \%$ of potential predator detections in camera traps (see also Vilà et al., 2004). Dogs were accompanied by people in $33.3 \%$ of detections, and the same individuals dogs were also detected alone. It is possible that some of the dogs detected were feral, and their presence in protected areas needs to be addressed. 
TABLE 1 Percentage frequency of occurrence of pudus in the diet of native carnivores in southern Chile, recalculated from the original sources as number of positive scats divided by total number of scats analysed.

\begin{tabular}{|c|c|c|c|c|}
\hline Frequency of occurrence $\%(n)$ & Location & Latitude & Longitude & Source \\
\hline \multicolumn{5}{|l|}{ Puma Puma concolor } \\
\hline $0.0(3)$ & Nahuelbuta & $37^{\circ} 47^{\prime}$ & $72^{\circ} 44^{\prime}$ & Rau \& Jiménez (2002b) \\
\hline $0.0(11)$ & Conguillío & $38^{\circ} 36^{\prime}$ & $71^{\circ} 36^{\prime}$ & Rau \& Jiménez (2002b) \\
\hline $67.7(31)$ & Rucamanque & $38^{\circ} 39^{\prime}$ & $72^{\circ} 36^{\prime}$ & Zúñiga et al. (2005) \\
\hline $26.5(65)$ & San Martín & $39^{\circ} 38^{\prime}$ & $73^{\circ} 07^{\prime}$ & Rau et al. (1991) \\
\hline $8.3(12)$ & San Martín & $39^{\circ} 38^{\prime}$ & $73^{\circ} 07^{\prime}$ & Rau \& Jiménez (2002b) \\
\hline $10.0(10)$ & Puyehue & $40^{\circ} 45^{\prime}$ & $72^{\circ} 12^{\prime}$ & Rau \& Jiménez (2002b) \\
\hline $50.0(26)$ & V Pérez R & $41^{\circ} 04^{\prime}$ & $71^{\circ} 50^{\prime}$ & Rau \& Jiménez (2002b) \\
\hline $100.0(3)$ & Huinay & $42^{\circ} 22^{\prime}$ & $72^{\circ} 25^{\prime}$ & J.E. Jiménez (unpubl. data) \\
\hline \multicolumn{5}{|l|}{ Guigna Leopardus guigna } \\
\hline $0.0(17)$ & Los Queules & $35^{\circ} 39^{\prime}$ & $72^{\circ} 41^{\prime}$ & Correa \& Roa (2005) \\
\hline $0.0(13)$ & Rucamanque & $38^{\circ} 39^{\prime}$ & $72^{\circ} 36^{\prime}$ & Zúñiga et al. (2005) \\
\hline $0.0(35)$ & Queulat & $44^{\circ} 35^{\prime}$ & $72^{\circ} 25^{\prime}$ & Freer $(2004)$ \\
\hline $0.7(135)$ & Lag. San Rafael & $46^{\circ} 39^{\prime}$ & $73^{\circ} 52^{\prime}$ & Freer (2004) \\
\hline \multicolumn{5}{|l|}{ Culpeo Lycalopex culpaeus } \\
\hline $0.0(18)$ & Los Queules & $35^{\circ} 39^{\prime}$ & $72^{\circ} 41^{\prime}$ & Correa \& Roa (2005) \\
\hline $0.0(107)$ & Niblinto & $36^{\circ} 45^{\prime}$ & $71^{\circ} 29^{\prime}$ & Torés (2007) \\
\hline $0.0(23)$ & Nahuelbuta & $37^{\circ} 47^{\prime}$ & $72^{\circ} 44^{\prime}$ & J.E. Jiménez (unpubl. data) \\
\hline \multicolumn{5}{|l|}{ Chilla Lycalopex griseus } \\
\hline $0.0(9)$ & Los Queules & $35^{\circ} 39^{\prime}$ & $72^{\circ} 41^{\prime}$ & Correa \& Roa (2005) \\
\hline $0.0(7)$ & Nahuelbuta & $37^{\circ} 47^{\prime}$ & $72^{\circ} 44^{\prime}$ & J.E. Jiménez (unpubl. data) \\
\hline $0.0(38)$ & Rucamanque & $38^{\circ} 39^{\prime}$ & $72^{\circ} 36^{\prime}$ & Zúñiga et al. (2005) \\
\hline $0.0(98)$ & San Martín & $39^{\circ} 38^{\prime}$ & $73^{\circ} 07^{\prime}$ & Martínez et al. (1993) \\
\hline $0.0(88)$ & San Martín & $39^{\circ} 38^{\prime}$ & $73^{\circ} 07^{\prime}$ & Rau et al. (1995) \\
\hline $0.0(223)$ & Centinela & $40^{\circ} 14^{\prime}$ & $73^{\circ} 04^{\prime}$ & Silva-Rodríguez (2006) \\
\hline \multicolumn{5}{|l|}{ Darwin's fox Lycalopex fulvipes } \\
\hline $0.2(404)$ & Nahuelbuta & $37^{\circ} 47^{\prime}$ & $72^{\circ} 44^{\prime}$ & Jiménez et al. (1991) \\
\hline $0.0(7)$ & Nahuelbuta & $37^{\circ} 47^{\prime}$ & $72^{\circ} 44^{\prime}$ & J.E. Jiménez (unpubl. data) \\
\hline $6.1(179)$ & Ahuenco & $42^{\circ} 06^{\prime}$ & $74^{\circ} 03^{\prime}$ & Jiménez (2007) \\
\hline $0.0(66)$ & Ahuenco & $42^{\circ} 06^{\prime}$ & $74^{\circ} 03^{\prime}$ & Elgueta et al. (2007) \\
\hline $3.9(88)$ & Piruquina & $42^{\circ} 24^{\prime}$ & $73^{\circ} 54^{\prime}$ & Jiménez et al. (1991) \\
\hline $0.0(25)$ & Tricolor & $42^{\circ} 49^{\prime}$ & $74^{\circ} 08^{\prime}$ & Rau \& Jiménez (2002a) \\
\hline $5.2(32)$ & Cipresal & $42^{\circ} 35^{\prime}$ & $74^{\circ} 08^{\prime}$ & Rau \& Jiménez (2002a) \\
\hline
\end{tabular}

Car hits are an important source of mortality for deer in general (Allen \& McCullough, 1976; Parker et al., 2008) and our data suggest that this could also be a conservation concern for pudus. Acknowledging that car collisions as a mortality source could be inflated (Spalding \& Forrester, 1993; Ciucci et al., 2007), it is not possible to compare its relative importance to other sources of mortality. However, the fact that car collisions appear to be important suggests that the planned construction of major highways in some of the best conserved areas of the region (Wilson et al., 2005) would require mitigation strategies.

\section{Implications for pudu conservation}

The main threat for pudu conservation is probably forest loss (Jiménez \& Ramilo, 2008) and the concomitant increase in incompatible human activities and land uses, which currently affect $>40 \%$ of the area originally covered by native forest in southern Chile (Cavelier \& Tecklin,
2005). The mortality sources described above may increase the negative effects of forest loss and fragmentation. Furthermore, pumas, the main native pudu predator, can tolerate some degree of forest loss (Muñoz-Pedreros \& Rau, 2005) and reductions in native prey availability by shifting their food preferences towards invasive and domestic species, which are abundant in non-forest habitats (Rau et al., 1991; Rau \& Jiménez, 2002b). As a result, predation pressure by pumas in fragmented landscapes may be an additional threat that has not been considered previously. Thus, as native forest is reduced to fragments, pudus may face the increasing and cumulative pressure of pumas, dogs and people (poaching and car collisions). Further understanding of how forest loss and mortality sources interact is important for developing effective strategies for the conservation of pudu.

Conserving pudus in human-dominated landscapes will require educating people to improve management of domestic dogs, and reduction of the impacts of illegal poaching. 
TABLE 2 Relative abundance indices (photographs per 100 trap-days) for eight mammal species detected in two areas in Chile (Fig. 1).

\begin{tabular}{|c|c|c|c|c|c|c|c|c|c|c|}
\hline \multirow[b]{3}{*}{ Species } & \multirow[b]{3}{*}{$\mathrm{N}^{1}$} & \multirow[b]{3}{*}{$\%$ diurnal $^{2}$} & \multicolumn{7}{|c|}{ Photographs per 100 trap-days $^{3}$} & \multirow[b]{3}{*}{ Overal } \\
\hline & & & \multicolumn{4}{|l|}{ Oncol area } & \multicolumn{3}{|c|}{ Valdivian Coastal Reserve } & \\
\hline & & & Pichicuyín & Oncol Park & Pilolcura & Overall & Chaihuín & Colún & Overall & \\
\hline European hare Lepus europaeus & 2 & 0.0 & 0.0 & 0.9 & 0.0 & 0.2 & 0.0 & 0.3 & 0.2 & 0.2 \\
\hline Domestic dog Canis lupus familiaris & 11 & 90.9 & + & 2.6 & + & 0.7 & 0.0 & 2.5 & 1.7 & 1.3 \\
\hline Chilla Lycalopex griseus & 4 & 0.0 & 1.5 & + & 0.0 & 0.5 & 0.0 & 0.6 & 0.4 & 0.5 \\
\hline Hog-nosed skunk Conepatus chinga & 8 & 0.0 & 0.0 & 0.0 & 1.2 & 0.5 & 0.7 & 1.6 & 1.3 & 0.9 \\
\hline Puma Puma concolor & 4 & 75.0 & 0.0 & 0.0 & 0.0 & 0.0 & 0.0 & 1.3 & 0.9 & 0.5 \\
\hline Guigna Leopardus guigna & 4 & 25.0 & 0.0 & + & 0.6 & 0.2 & + & 0.9 & 0.6 & 0.5 \\
\hline Pudu Pudu puda & 10 & 70.0 & 0.7 & 0.0 & 0.0 & 0.2 & 5.3 & 0.3 & 2.1 & 1.1 \\
\hline Cattle Bos taurus & 20 & 90.0 & 2.2 & + & 1.2 & 1.2 & 0.0 & 4.7 & 3.2 & 2.3 \\
\hline Total trap-days & & & 136 & 114 & 162 & 412 & 151 & 318 & 469 & 881 \\
\hline
\end{tabular}

${ }^{1}$ number of independent records

${ }^{2}$ percentage of photographs obtained during daylight hours

${ }^{3}+$, species observed during our work in the area but not detected at camera traps

Steps toward this are being taken, with the preparation of educational material for farmers (C. Smith-Ramírez et al., in preparation) that includes the findings of this study, and the provision of feedback to the relevant protected area authorities. In ongoing research we are evaluating how domestic dog and cat Felis catus management influences predation on wildlife, and how the interaction of forest loss with other anthropogenic threats may affect pudu survival.

\section{Acknowledgements}

The authors thank Jaime Jiménez, Kathryn E. Sieving and two anonymous reviewers for valuable comments on the manuscript. We thank the US Fish \& Wildlife Service Latin American \& Caribbean Program and the Valdivian Coastal Reserve and its park rangers, Parque Oncol, the Darwin Initiative, José Vistoso, Alfredo Almonacid, Pablo Lépez, Jaime Jiménez, Roguet Alba, Pascual Alba and all volunteers of wildlife rehabilitation centres at the Universidad de Concepción and the Universidad Austral de Chile for logistical support. EAS was supported by a FulbrightConicyt fellowship. CV was supported by a MIDEPLAN International Scholarship.

\section{References}

Allen, R.E. \& McCullough, D.R. (1976) Deer-car accidents in southern Michigan. Journal of Wildlife Management, 40, $317-325$.

Cavelier, J. \& Tecklin, D. (2005) Conservación de la Cordillera de la Costa: un desafío urgente en la ecorregión valdiviana. In Historia, biodiversidad y ecología de los bosques costeros de Chile (eds C. Smith-Ramírez, J.J. Armesto \& C. Valdovinos), pp. 632-641. Editorial Universitaria, Santiago, Chile.

Ciucci, P., Chapron, G., Guberti, V. \& Boitani, L. (2007) Estimation of mortality parameters from (biased) samples at death: are we getting the basics right in wildlife field studies? A response to Lovari et al. (2007). Journal of Zoology, 273, 125-127.

Correa, P. \& RoA, A. (2005) Relaciones tróficas entre Oncifelis guigna, Lycalopex culpaeus, Lycalopex griseus y Tyto alba en un ambiente fragmentado de la zona central de Chile. Mastozoología Neotropical, 12, 57-60.

Dimaio, V.J.M. \& DiMaio, D. (2001) Forensic Pathology, 2nd edition. CRC Press, Boca Raton, USA.

Eldridge, W.D., MacNamara, M.M. \& Pacheco, N.V. (1987) Activity patterns and habitat utilization of pudus ( $P u d u$ puda) in south-central Chile. In Biology and Management of the Cervidae (ed. C.M. Wemmer), pp. 352-370. Smithsonian Institution Press, Washington, DC, USA.

Elgueta, E.I., Valenzuela, J. \& Rau, J.R. (2007) New insights into the prey spectrum of Darwin's fox (Pseudalopex fulvipes Martin, 1837) on Chiloé Island, Chile. Mammalian Biology, $3,179-185$.

Franklin, W.L., Johnson, W.E., Sarno, R.J. \& Iriarte, J.A. (1999) Ecology of the Patagonia puma Felis concolor patagonica in southern Chile. Biological Conservation, 90, 33-40.

FREER, R.A. (2004) The spatial ecology of the güiña (Oncifelis guigna) in southern Chile. PhD thesis, University of Durham, Durham, UK.

Hershoovitz, P. (1982) Neotropical deer (Cervidae). Part 1. Pudus, genus Pudu Gray. Fieldiana Zoology, New Series, 11, 1-86.

JiMÉNEZ, J.E. (2007) Ecology of a coastal population of the critically endangered Darwin's fox (Pseudalopex fulvipes) on Chiloé Island, southern Chile. Journal of Zoology, 271, 63-77.

Jiménez, J.E., Marquet, P.A., Medel, R.G. \& Jaksic, F.M. (1991) Comparative ecology of Darwin's fox (Pseudalopex fulvipes) in mainland and island settings of southern Chile. Revista Chilena de Historia Natural, 63, 177-186.

Jiménez, J.E. \& Ramilo, E. (2008) Pudu puda. In IUCN Red List of Threatened Species v. 2009.1. Http://www.iucnredlist.org [accessed 13 August 2009].

Martínez, D.R., Rau, J.R., Murúa, R.E. \& Tilleria, M.S. (1993) Depredación selectiva de roedores por zorros chillas (Pseudalopex griseus) en la pluviselva valdiviana, Chile. Revista Chilena de Historia Natural, 66, 419-426.

Mazaris, D.A., Mamakis, Y., Kalpakis, S., Poulopoulos, Y. \& Matsinos, G.Y. (2008) Evaluating potential threats to birds in Greece: an analysis of a 10-year data set from a rehabilitation centre. Oryx, 42, 408-414. 
Meier, D. \& Merino, M.L. (2007) Distribution and habitat features of southern pudu (Pudu puda Molina, 1782) in Argentina. Mammalian Biology, 72, 204-212.

Miller, S., Rottmann, J. \& Taber, R. (1973) Dwindling and endangered ungulates of Chile: Vicugna, Lama, Hippocamelus and Pudu. Transactions of the North American Wildlife and Natural Resources Conference, 38, 55-68.

Muñoz-Pedreros, A. \& Rau, J. (2005) Presencia y densidad de pumas (Puma concolor) en dos localidades de la cordillera de la Costa del sur de Chile. In Historia, biodiversidad y ecología de los bosques costeros de Chile (eds C. Smith-Ramírez, J.J. Armesto \& C. Valdovinos), pp. 539-540. Editorial Universitaria, Santiago, Chile.

Parker, I.D., Braden, A.W., Lopez, R.R., Silvy, N.J., Davis, D.S. \& OWen, C.B. (2008) Effects of US 1 Project on Florida Key deer mortality. Journal of Wildlife Management, 72, 354-359.

RAU, J. \& JiméneZ, J.E. (2002a) Dieta otoño-invernal del zorro de Darwin: una comparación entre dos hábitats de Chiloé, Chile. Gestión Ambiental (Chile), 8, 57-62.

RAU, J.R. \& JiméneZ, J.E. (2002b) Diet of puma (Puma concolor, Carnivora: Felidae) in coastal and Andean ranges of southern Chile. Studies in Neotropical Fauna and Environment, 37, 201-205.

Rau, J.R., Martínez, D.R., Low, J.R. \& Tilleria, M.S. (1995) Depredación por zorros chillas (Pseudalopex griseus) sobre micromamíferos cursoriales, escansoriales y arborícolas en un área silvestre protegida del sur de Chile. Revista Chilena de Historia Natural, 68, 333-340.

Rau, J.R., Tilleria, M.S., Martínez, D.R. \& Muñoz, A.H. (1991) Dieta de Felis concolor (Carnivora: Felidae) en áreas silvestres protegidas del sur de Chile. Revista Chilena de Historia Natural, 64, 139-144.

Silva - Rodríguez, E.A. (2006) Evaluación de conflictos entre zorros chilla (Pseudalopex griseus) y agricultura de subsistencia en una localidad rural del sur de Chile: ¿mito o realidad? DVM thesis, Universidad Austral de Chile, Valdivia, Chile.

Silveira, L., JÁcomo, A.T.A. \& Diniz-Filho, J.A.F. (2003) Camera trap, line transect census and track surveys: a comparative evaluation. Biological Conservation, 114, 351-355.

Spalding, M.G. \& Forrester, D.J. (1993) Disease monitoring of free-ranging and released wildlife. Journal of Zoo and Wildlife Medicine, 24, 271-280.
Torés, N. (2007) Dieta estival del culpeo (Pseudalopex culpaeus, Molina 1782) en Nevados de Chillán, centro-sur de Chile. DVM thesis, Universidad Austral de Chile, Valdivia, Chile.

Vilì, C., Leonard, J.A., Iriarte, A., O’Brien, S.J., Johnson, W.E. \& WAYNE, R.K. (2004) Detecting the vanishing populations of the highly endangered Darwin's fox, Pseudalopex fulvipes. Animal Conservation, 7, 147-153.

Weber, M. \& González, S. (2003) Latin American deer diversity and conservation: a review of status and distribution. Ecoscience, $10,443-454$.

Wemmer, C. (1998) Deer: Status Survey and Conservation Action Plan. IUCN/SSC Deer Specialist Group, IUCN, Gland, Switzerland.

Wilson, K., Newton, A., Echeverría, C., Weston, C. \& BURGMAN, M. (2005) A vulnerability analysis of the temperate forests of south central Chile. Biological Conservation, 122, 9-21.

Woodford, M.H., Keet, D.F. \& Bengis, R.G. (2000) Post-Mortem Procedures for Wildlife Veterinarians and Field Biologists. Office International des Epizooties, Care for the Wild International and IUCN, Paris, France.

Zúñiga, A., Quintana, V. \& Fierro, A. (2005) Relaciones tróficas entre depredadores en un ambiente fragmentado del sur de Chile. Gestión Ambiental (Chile), 11, 31-42.

\section{Biographical sketches}

Eduardo A. Silva-Rodríguez is a veterinarian interested in the ecology and conservation of wildlife in human-dominated landscapes, with particular research interests in the interactions between domestic carnivores and wildlife, and human-wildlife conflicts. CLAUDIO VERDUGO is a wildlife veterinarian, focusing on the ecology of infectious diseases in wild animal populations, especially in genetic determinants of susceptibility to viral diseases. AlEJANDRO A LEUY is the veterinarian responsible for the wildlife rehabilitation centre at Universidad Austral de Chile. James G. SANDERson is a fellow of the Wildlife Conservation Network, founder of the Small Cat Conservation Alliance and a member of the IUCN Cat Specialist Group. GABRIEL R. Ortega-Solís is a veterinarian who carries out research on wildlife ecology in human-dominated landscapes. FELIPE OSORIO-ZÚNIGA is interested in the ecology and systematics of bryophytes. Daniel González-Acuña conducts research on parasitic diseases of wild animals. 